\title{
High-stakes testing policy and English language teaching: Voices of the leftovers
}

\author{
Laser Romios * ${ }^{\text {, }}$, Ashadi ${ }^{2}$, Widyastuti Purbani ${ }^{3}$ \\ 1,2,3 Department of English Education, Faculty of Teacher Training, Yogyakarta State \\ University, Sleman, Yogyakarta, Indonesia \\ * laserromios@gmail.com (Corresponding Author)
}

\begin{abstract}
High-stakes testing has been controversial in many countries for several impacts and reasons surrounding its implementation. Teachers' voices should be heard for well-rounded education policy. This study aims to investigate the voices of English teachers on the impacts of the national exam (NE) towards English language teaching at junior high schools (JHS) in Yogyakarta, Indonesia. It is a qualitative study involving three private JHSs and three state JHSs, chosen according to their NE-based ranks: low, mediocre, and high performing - for inclusive representation. The subjects are six English teachers from six JHSs. The data were collected through interviews and analyzed using the analysis model of Miles, Huberman, and Saldana, following the steps of data condensation, data categorization, data display, data interpretation, and conclusion drawing and verification. The findings show that NE leads to low order thinking skills, digresses from the goals of curriculum 2013, prioritizes only knowledge, focuses on English passive skills, induces favoritism between teachers, and disables teachers to vary their teaching strategies. Teachers' involvement in education policy is necessary, and they are generally in favor of NE abolishment plan. The implication of this study calls for implementing teachers' coping mechanism in transitioning from NE to the newly proposed assessment.
\end{abstract}

Keywords: high-stakes testing; teachers' voices; English language teaching; education policy; national exam (NE) 
How to cite this paper (in APA style): Romios, L., Ashadi, \& Purbani, W. (2020). High-stakes testing policy and English language teaching: Voices of the leftovers. Journal on English as a Foreign Language, 10(2), 193-221. https://doi.org/10.23971 /jefl.v10i2.2005

DOI: https://doi.org/10.23971 ßefl.v10i2.2005

\begin{tabular}{|c|c|}
\hline (c) (†) (?) & Copyright (C) 2020 THE AUTHOR(S). This article is distributed under a Creative \\
\hline
\end{tabular}

High-stakes testing refers to an examination that determines a person's academic career or job opportunities (Crawford \& Impara, 2001; Franzak, 2004; Spring, 2004). It also concerns the mastery of academic standards required for graduation (Cochran-Smith, 2003; Guthrie, 2002; Jones et al., 2003). Thus, it can be summed up that students will fail their studies if they do not succeed in such an exam. The work of teachers around the world has been affected by highstakes testing (Au, 2011; Berliner, 2011; Braun et al., 2010), including the shifts of student achievement within a certain set of allocated time (Diamond, 2013), changes in education mission (Braun et al., 2010), teachers' profession reconfigurations (Cochran-Smith, 2006), and alterations in the area of teacher education (Wepner, 2006). This proves that high-stakes testing has multiple impacts towards ELT, teachers, students, and education system. ELT classsroom instructions have been disrupted while the goals of education have been shifted to score-oriented system. Further, high stakes testing has changed students' mindset about education essence, skewing their thought into thinking that score is the paramount core of education success.

Despite these effects, the implementation of high-stakes testing for school quality has risen in numerous countries worldwide (Deville \& Chalhoub-Deville, 2011). Arguments for accepting high-stakes testing may include the notion that imposing penalties to test scores will keep teachers motivated. Students also become more enthusiastic to work harder and that the test outcome shows a personal performance (Nichols \& Berliner, 2007). On the contrary, diverging views against high-stakes testing have become heated up since previous studies have suggested unintended consequences of high-stakes testing, including segregations of students who are considered impossible to perform well in the test (Darling-Hammond, 2010; Stobart, 2008), much effort for intensive test preparation (Alexander, 2010; Stobart, 2008), and cheating (Nichols \& Berliner, 2007). It is implied that high-stakes testing creates a divide between academicians and education stakeholders. The academicians are generally against high-stakes testing and have proven that it hinders learning

Journal on English as a Foreign Language, 10(2), 193-221

p-ISSN 2088-1657; e-ISSN 2502-6615 
from taking place properly while the education stakeholders still want it to continue for its practicality in instant education improvement measure. The severity of the trade-off within the implementation of high-stakes testing is still debatable until today.

Other studies reveal that high-stakes testing causes teachers to quit collaborative learning practice, integrated learning and inquiry-driven learning for the sake of isolated and split test practice in basic skills (Au, 2009; BarksdaleLadd \& Thomas, 2000; Dutro \& Selland, 2012). It also causes students to be anxious, students' parents to be worried about their children's future, schools to bear strains to keep their reputation afloat, and induce dishonesty and cheating (Coniam \& Falvey, 2018; Harris et al., 2011; Kempf, 2016; Thomas, 2005). These effects are also evident in Indonesia. National Exam (NE), a high-stakes test administered yearly, is aimed at assessing school effectiveness and is taken by students sitting in their final years, such as grade 6 (primary school), grade 9 (junior high school), and grade 12 (senior high school). The implementation of this high-stakes testing has generated disputes in the public, with experts and researchers questioning its effectiveness and validity.

Schools in Indonesia often teach materials tested in NE, causing attitude and skills to be eliminated from the education experience and curriculum to be narrowed down to suit its goals (Alhadza \& Zulkifli, 2017; Mustajib, 2017), leaving students losing the chance to sufficiently acquire English skills. As such, students' parents are worried about their children's future (Saukah \& Cahyono, 2015), encouraging them to send them to an English course for better English education. In a worse case, students are anxious when NE is already around the corner, feeling pressured whether they can achieve their targeted score and satisfy their parents' expectations (Sundayana et al., 2018). This might be related to the scandal where school principals asked teachers to secretly provide an answer key to their students (Mukminin et al., 2013). This high-stakes testing has also made an education authority in Medan pay the price; a student-Gita Saraswati-sued them over her NE failure despite her being intelligent (Merdeka, 2013). More tragically, a student of a vocational school in the same region committed suicide due to being accused of posting an answer key on a social media platform (BBC Indonesia, 2017). Recently, an IT staffer of a senior high school in Surabaya hacked the online testing system and distributed the answer key to the students through WhatsApp (Antaranews, 2018). NE has also directly created a new psycho-social phenomenon of mass prayer involving teachers, principals, students and even parents, believed to make students feel relaxed and confident prior to the NE (Kurniasari, 2016; Maisaroh \& Falah,

Journal on English as a Foreign Language, 10(2), 193-221

p-ISSN 2088-1657; e-ISSN 2502-6615 
2011). However, Alhadza and Zulkifli (2017) also found that NE is still useful for improving and distributing education quality despite it being no longer the determinant of graduation. This clearly shows that the disadvantages of NE outweigh its benefits. The impacts affect teachers and students, both physically and emotionally. All these effects have been going on for so long in education system in Indonesia. This might be why the general public, experts and researchers pressured the government to pass education system reform.

There have been some changes in NE, especially in English subject. English has been tested in multiple-choice since its birth as to assess the final year students and the outcome was considered as students' graduation outcome (Yulia, 2014). In 2011, the NE outcome was no longer the sole determinant, weighing only $60 \%$ of the whole score (Mukminin et al., 2013; Yulia, 2014). In 2015, a new education policy was issued, leaving NE no longer the sole determinant of students' graduation (Ministry of Education and Culture Regulation Number 5 Year 2015). Since then, students' graduation has been determined by their academic achievements set by schools through Ujian Sekolah Berbasis Nasional/National-based School Test (USBN) combined with NE score. Nevertheless, the policy change still affected English teachers and their ELT classrooms. They cannot cater for the requirements of curriculum 2013 (henceforth K-13), sacrificing the assessment for attitude and skills while prioritizing students' preparation for NE. This mentally tortures and pressures teachers as schools and the education authority still demand high scores in the NE. From here, teachers' grievances to education policy began to burst. Despite education decentralization that has been going for decades now, the education policy still does not accommodate teachers' aspirations. Teachers have always wanted their voices to be heard and considered in education policy making, especially concerning curriculum and assessment. However, little room is given to them for involving in education policy reform; and this issue becomes the backdrop of this study, focusing on teachers' voices and attempting to reveal their concerns regarding NE amidst its status as no longer being a graduation determinant.

In 2019, the current minister of education and culture Nadiem Makarim announced that NE will have been lifted from the education policy by 2021 (The Jakarta Post, 2019). This reform goal is to create an education revolution, making assessment system more flexible and personalized, giving teachers freedom in classroom activities, and shifting education goals. However, the researchers' encounters with English teachers revealed that NE has shaped the existing teachers' mindset-being firmly used to the older education system

Journal on English as a Foreign Language, 10(2), 193-221

p-ISSN 2088-1657; e-ISSN 2502-6615 
where NE score affects students' future and being already complacent in their ELT classrooms under NE-specified teaching materials. Conversely, some teachers complained and felt pressured by NE as it makes them teach to the test, seeing it as a restriction in varying teaching strategies and supplying students with attitude, skill and knowledge as mandated by K-13. The majorities expect education policy change and are particularly in favor of $\mathrm{NE}$ abolishment, believing NE is no longer relevant with the current educational trend.

Since 2016 up to date, the students' graduation has been determined by their characters evaluation and achievement score as the total outcome. The researchers' encounters with the teachers revealed that they found a dilemma in administration and ELT instruction. The school-based test score must reflect the score of the NE; otherwise their report will be questioned. They also said that they are frustrated when they still have to follow the materials that are catered for NE framed within the curriculum. Thus, the easing of NE as no longer the determinant of graduation still induces problems to some degree.

Teachers' perspectives on NE vary widely. Hartaty (2017) found that respondents' perception towards the implementation of such a policy was positive. All participants agreed that the new NE policy is different from that of the previous one, by admitting that the new policy supports them to be more effective and engaging in ELT classroom instructions. One teacher believed that the new policy freed her from pursuing score targets, having more freedom to the pace of ELT. Thus, he could teach the communicative language teaching practices as mandated by the new policy. Indrawati (2018) found that NE caused teachers to teach students through drills. They tend to neglect the other materials that are beyond the simulation tests of NE. Ashadi and Rice (2016) found that teachers see NE as the breeding ground of discrimination on teacher professionalism development. Effendi and Suyudi (2017) revealed that teachers believed that they are confined in a comfort zone as they have to repeat the same materials every year, making them demotivated to improve their teaching strategies. Nahdia and Trisnati (2019) found that teachers view NE mostly in positive side, implying they are more motivated to teach students through various methods and media to prepare their students for it. All these studies were conducted when NE was still firmly in place. On the contrary, the current study is focused on the voices of the leftovers where NE was already at its last day prior to its abolishment.

Journal on English as a Foreign Language, 10(2), 193-221

p-ISSN 2088-1657; e-ISSN 2502-6615 
Little research has been thoroughly conducted on the curriculum digression that overlooks attitude, skills and critical thinking assessment. In addition, no research has dug deep into the coping mechanisms and aspirations of the teachers who are transitioning from NE-centered ELT and assessment to a more customized teaching method through the design of Minimum Competency Assessment and Character Survey. How school zonation affects the status of NE outcome has been barely researched. With the limited knowledge and research in the issue, this study will dig deeper into how NE affects ELT and what teachers' concerns are related to curriculum and education policy. In addition, their ways of transitioning from NE-driven to a more personalized teaching method will also be elaborated. To gain an in-depth understanding of this issue, this study will attempt to answer these research questions, "What are teachers' voices towards the effects of NE on the practice of ELT in classrooms?", "How do they make sense of their teachings in response to the goals of NE?", "What are teachers' concerns towards how NE influences teachers' professionalism and psychology?", and "What are teachers' voices towards the abolishment of NE?"

\section{METHOD}

\section{Research Design}

A qualitative study approach was employed to extract the participants' voices through a descriptive narrative manner. Mohajan (2018) and Merriam (2009) state that qualitative research is used by researchers to understand the meaning constructed by people regarding how people make sense of the world and how they experience it. This method is used to unpack the essences and essentials of the participant meanings (Saldaña, 2011). The researchers listened to, analyzed, and interpreted teachers' voices considering that they are an internal stakeholder directly affected by the NE policy. Teachers are one of the main actors in the education policy implementation since they do the teaching to reach the learning goals set in the curriculum including the NE. Thus, they directly experience the impacts of such unaligned policy. This study identified the voices of teachers towards the consequences of NE towards ELT, particularly their classroom practice. A face-to-face interview was conducted in this study, aimed at accommodating unsuspected topics and enhancing the interviewer to establish comprehension of the interviewees' points of view (Zhang \& Wildemuth, 2009). The number of the interviewees in the current study is 6, which is considered small. However, it is not an issue in a qualitative

Journal on English as a Foreign Language, 10(2), 193-221

p-ISSN 2088-1657; e-ISSN 2502-6615 
study since its main goal is to encourage respondents to deeply articulate their messages about a situation or program (Boyce \& Neale, 2006).

\section{Participants}

This study employed a purposive sampling technique where six teachers became the participants from six different schools in Yogyakarta city, three are state-owned and three others are private-run. They satisfied the qualifications of this study, including being an English teacher, having had at least 5 years of teaching experience, and being eloquent in expressing their voices. They represent low, mediocre, and high performing schools. What makes this study distinctive is that it was conducted in Yogyakarta, a special province often associated with the benchmark of Indonesian national education. Table 1 shows the participants' profile of the current study which includes the participants' name, school name, school category, gender, employment status, and English teaching experience duration. To protect human subjects and prevent potential risks that may occur later, the names of the schools and teachers are altered into pseudonyms.

Table 1. Participants' profile

\begin{tabular}{lccccc}
\hline Teacher & School & $\begin{array}{c}\text { School } \\
\text { category }\end{array}$ & Gender & $\begin{array}{c}\text { Employment } \\
\text { status }\end{array}$ & $\begin{array}{c}\text { English } \\
\text { teaching } \\
\text { experience } \\
\text { (years) }\end{array}$ \\
\hline Ava & Ainsle & State & Female & Full-time & 16 \\
Barbara & Bonython & Private & Female & Full-time & 10 \\
Catalina & Calwell & State & Female & Full-time & 26 \\
Dalton & Duffy & Private & Male & Full-time & 6 \\
Elizabeth & Evatt & State & Female & Full-time & 14 \\
Florence & Fraser & Private & Female & Full-time & 6 \\
\hline
\end{tabular}

The teachers above were assigned by each school's principle upon the researchers' requests, with eloquence and teaching experience duration being the criteria. This enabled the researchers to dig deeper into their teaching experiences and voices towards how NE affects ELT. The selected schools represent low, mediocre, and high performing institution based on the NE result rank released by the district, from academic year 2016 to 2019. This sampling was meant to represent the voices of teachers from schools whose students are from different socio-economic status and academic achievement. From this variety, this study is expected to capture the thick description of the phenomenon and to eliminate biased views.

Journal on English as a Foreign Language, 10(2), 193-221

p-ISSN 2088-1657; e-ISSN 2502-6615 


\section{Data Sources}

An open-ended interview guideline containing 20 questions was used to stimulate participants to share their experiences and stories. It covered various aspects, including: the teachers' English teaching background, general knowledge on NE, teaching methods, the effects of NE on ELT processes, the relation between students' backgrounds, academic abilities and school facilities with students' achievement in NE, the goals of NE, how NE influences teachers' professionalism and psychology, and their envision on NE abolishment. This set of inquiry was aimed at identifying teachers' concerns towards the challenges in ELT classroom that should cater for NE goals and revealing their psychological state caused by NE. The questions also induced them to voice their thoughts on NE policy and its relation to curriculum. Topics regarding teachers' envision on whether the government should discontinue NE, alternative assessment, and likely consequences of NE abolishment were also explored.

\section{Data Collection}

Prior to collecting the data, the researchers distributed the consent to the schools and teachers to earn their agreement to participate in the study. After explaining the purpose of the study and receiving the consent, the researchers went to the schools at the agreed time and interviewed the teachers at their respective schools, with each session lasting 40 - 50 minutes. Before the interview commenced, the researchers read brief information regarding the aim of the study, its significance, and the procedures and prevention of human subject threats to keep them safe. Consent to record the interview by using a cellphone was asked and the recording began after an agreement. To enhance the interview session, some note-taking was also done. The recordings and notes assisted the researchers in doing transcription with high accuracy. Pseudonyms were employed to each participant (Ava, Barbara, Catalina, Dalton, Elizabeth, Florence) and school (Ainsle, Bonython, Calwell, Duffy, Evatt, Fraser) for the sake of participants' confidentiality and risks prevention. To keep the interview relaxed but deep and focused, the researchers followed the leads of informants and probed into emergent areas during the interview sessions. Thus, the interview went well as planned.

\section{Data Analysis}

For data analysis, the researchers used the theory by Miles, Huberman, and Saldaña (2014), which includes data condensation, data categorization, data

Journal on English as a Foreign Language, 10(2), 193-221

p-ISSN 2088-1657; e-ISSN 2502-6615 
display, data interpretation, and conclusion drawing or verification. The transcribed interview data were sent back through email to the interviewees for verification purposes. After receiving their approval, the researchers read and reread the data while coding important information thematically by using a table. This categorization stage led to 4 emerging main themes: teachers' voices towards the effects of NE on the process of ELT in classrooms; their voices on the goals of NE; the effects of NE on their professionalism and psychology; teachers' voices on the abolishment of NE. For a more accurate analysis, the categories from each transcript were constantly compared to find a comprehensive pattern so that each could be appropriately interpreted. To enhance the trustworthiness of the study, peer debriefing and double crosscheck were conducted by sharing the analysis result with all co-researchers for deeper data interpretation and confirming it back to the participants for verification. After their approval, a conclusion was drawn visually to facilitate further explanatory claims. This method was used to avoid misstatements, misrepresentations, or fraudulent analyses (Lichtman, 2010).

\section{FINDINGS}

Teachers' voices from each school were arranged and further scrutinized for emerging themes and arguments. Then, they were discriminated and constantly compared with each other. The voices from the interviewed teachers were put in codes and then analyzed across participants. This section will dive deep into four key issues, including: teachers' voices towards the effects of NE on the process of ELT in classrooms, their voices on the goals of NE, the effects of NE on teachers' professionalism and psychology, and teachers' voices on the abolishment of NE. To sum up, Figure 1 represents the findings of this study which are organized in line with the research questions.

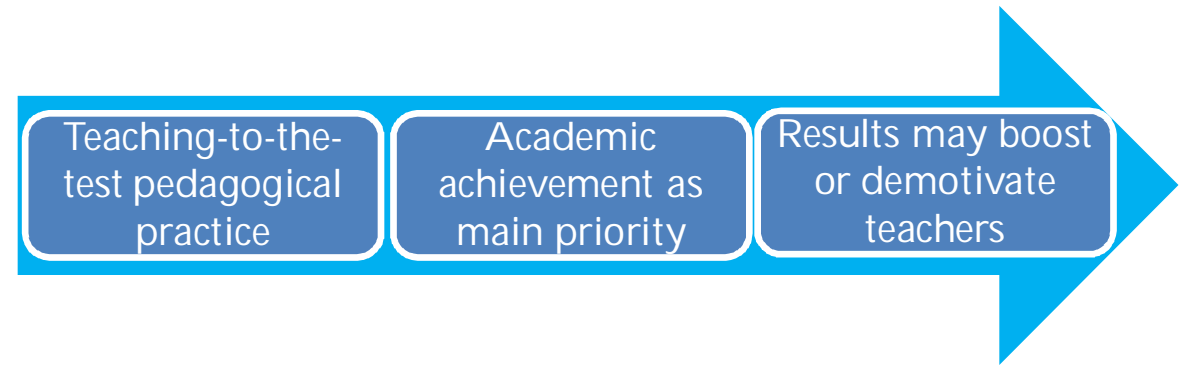

Figure 1. How NE affects ELT and ELT teachers

Figure 1 implies that NE shapes the teaching method used by teachers, which is teaching to the test. This occurs because the teachers are dictated to achieve the goal of education - where high NE scores are paramount. They

Journal on English as a Foreign Language, 10(2), 193-221

p-ISSN 2088-1657; e-ISSN 2502-6615 
limit the ELT method to drilling and direct teaching. The combination of the forced education system and affected teaching method results in two consequences: teachers being motivated to teach due to such stiff system and teachers being demotivated due to frustration of being shackled by such rigid policy. This situation will be further elaborated in the following paragraphs.

\section{Teachers' Views on the Impacts of NE on Pedagogical Practice}

Teachers are affected by the presence of NE with various severities, one of which being teachers losing freedom in choosing teaching materials due to narrowed curriculum. Ava, a teacher from Ainsle school, complained about the NE-driven curriculum. In a statement she said:

I feel as if I am being dictated. I keep ruminating my teaching activity. All that lingers in my mind is the outlines [of the NE questions].

Ava, as seen in the excerpt above, feels obliged to teach all the materials indicated by the curriculum. She wants to teach the students' wants and needs but she does not have the chance to do so since the prescribed learning materials are already overloaded with the standardized themes. This causes her to be stripped of teaching freedom, leaving no room to materials diversification. Similarly, Dalton, a teacher from Duffy school, maintained that all schools use the same framework so that the students can answer NE questions uniformly. He stated:

Students are tested with 2 simulation tests; one is made by the government while the other by the school. In spite of the questions being formulated by two different entities, the contents of the questions are similar.

Dalton has dealt with ELT for more than 5 years and he admits that the types of questions have been the same from the start. His statement suggests that the curriculum expects teachers to repeat the same materials every year. This may seem convenient for them, but it gradually degrades their teaching creativity, preventing them from exploring and developing their students' potential and communication skills.

Furthermore, NE forces teachers to teach anything that leads to students' reading skill development since the NE questions are mostly text-based. Barbara, a teacher from Bonython school, said in a statement:

Journal on English as a Foreign Language, 10(2), 193-221

p-ISSN 2088-1657; e-ISSN 2502-6615 
... Since the time is too tight [for NE preparation], I will pity my students if I teach them Listening and Speaking more than Reading. I am worried if they might be unable to keep up with Reading. So yeah, NE greatly influences [what I teach].

Thus, Barbara believes that teachers shrink their teaching materials to fit NE requirements. NE uses multiple-choice questions in reading passages without critical thinking stimulation, contradicting the principles of ELT.

Correspondingly, NE caused ELT paradigm shift, shown by teachers' concern over the contradiction between K-13 - which mandates a well-rounded education-and NE-which assesses only a partial element of education. As such, Catalina, a teacher from Calwell school, put it in a statement:

NE requires students to master knowledge [of the mandatory lessons taught]. In the meantime, attitude and skills are also supposed to be learned at school. [Due to NE] I prioritize knowledge over the rest. Thus, I search for the information about what will be on NE and then give it to students. I prioritize what's more important.

Catalina further explained that even though K-13 demands teachers to teach students not only knowledge but also skills and attitude, she cannot do so because she puts her biggest effort on making them succeed in NE. The success of NE is measured by the scores of students' general knowledge through textbased memorization. This puts her in a dilemma; she wants to implement all the curriculum requirements but NE fails her to realize them since they take over the whole process of ELT.

\section{Teacher Expectation from the NE Outcome}

Ava, Elizabeth (a teacher from Evatt school), and Florence (a teacher from Fraser school) believed that NE has caused students to be more motivated when under pressure of satisfying NE. Ava said:

The positive thing of NE is that the students are motivated to read. It's a kind of stimulus for them to read what they should read. The English language lesson is still unspecified, suggesting what they read may vary. They acquired various vocabularies.

Similarly, Elizabeth said:

Journal on English as a Foreign Language, 10(2), 193-221

p-ISSN 2088-1657; e-ISSN 2502-6615 
NE motivates students to study seriously since they know that NE score can help improve their overall score for the graduation.

In a similar tone, Florence said:

The fact that NE has a little weight or percentage for the overall score for graduation doesn't change students' motivation to score high in NE. They do whatever it takes to get the best score.

Since the topics of NE reading passage vary, students have to read diverse reading selections so that they will be able to answer all the questions. Having rich array of vocabulary keeps them safe from getting stuck in difficult words. As anticipation for NE, they push themselves into constantly studying English hard for the highest score possible. Since they realized that NE score can upgrade their overall score, they study very hard so that they can apply for the best school through a merit-based application. This shows that the trace of NE legacy has not entirely disappeared until today.

NE was the only test that measures students' learning performance for decades. It could be due to the increased protest from the public that it has now been abolished and changed into non-determinant score for graduation. Despite considered as such, it still plays an important role in school admissions. Cataline said:

... Still, NE is used to apply for a senior high school and to identify school qualities.

Cataline further elaborated that every highly reputable school has an admission quota for high achieving students despite school zonation system. NE contributes $40 \%$ of the total final score after being combined with school-based tests.

Whether the curriculum goals have been achieved is shown by NE outcome. As such, Florence agreed to it, saying in a statement:

NE is still vital since it is still used to measure how well we have achieved the curriculum requirements. It is a benchmark of our education quality."

Florence implied that if the NE score is high, the curriculum goals have been accomplished. Some teachers have the belief that what is tested in NE reflects the whole things that the students need to study, leading to the notion that NE

Journal on English as a Foreign Language, 10(2), 193-221

p-ISSN 2088-1657; e-ISSN 2502-6615 
is a reliable tool to determine the quality of education in Indonesia, representing the ability of the teachers, principals, and education authorities to run education.

\section{The Strength of NE Influence on Teachers' Professionalism and Psychology}

NE benefits those who teach the NE-tested subjects, particularly English subject. English teachers are happy with their professional status because they gain more attention from the education authority. Elizabeth confirmed this special treatment, stating:

... Being a teacher who teaches a subject that is tested in NE like English gives us some kind of pride and privilege to a certain degree.

Elizabeth admitted that English teachers have more access to self-development such as teaching training. They are given this priority since they are supposed to perform well in order that the schools will score high in NE, which then will earn them a good reputation from the education authority. This makes teachers more competitive and enthusiastic at work and the government allocates more budget for couching clinics for these teachers to materialize education success. However, this special treatment results in a dilemma; the non-prioritized teachers grow jealousy over this picky attention, thinking that they are less important the prioritized ones.

Psychology-wise, teachers suffer from anxiety and stress due to the pressure from NE being an indicator of school quality and students' English learning success. This is shown by Ava within her statement:

... Yes, of course, I always feel haunted by NE even though I am teaching at Ainsle school [best performing school] like this. There is a kind of target that is not necessarily suitable with my want. Oftentimes I feel sinful and anxious. Students often wonder why they have to spend so much time taking simulation tests when the outcome is never satisfying.

Ava said that there are things that should not be taught, including excessive reading passages. Some of the reading materials are considered as less important or not applicable to students' future life. For example, students have to study very specific and rare animals that they have barely heard of before. Furthermore, Ava felt as if she had been guilty when she failed to meet students' expectation on scoring high. To reduce this conflict of interest,

Journal on English as a Foreign Language, 10(2), 193-221

p-ISSN 2088-1657; e-ISSN 2502-6615 
teachers usually rely on simulation tests despite being different from the real tests.

Similarly, teachers feel embarrassed when regarded as a failed teacher. In this case, Florence mentioned that the outcome of NE reveals her teaching ability, as articulated in her statement:

I feel as if I failed to deliver materials to students if their score is low. I am like a big failure. If my school doesn't perform well in $\mathrm{NE}$, the education authority will strongly warn us to improve. This devastates my confidence in being a teacher.

Such justification does not seem fair considering there are other factors that also influence the outcome of NE, including nervousness and being physically unfit during the test. Ironically, these outliers are often overlooked by the education authority, resulting in teachers feeling incapable of their job and losing their confidence in their ELT classrooms. Such an issue equally concerns Barbara, as citied in her statement:

After every NE, all schools are invited to attend an evaluation meeting. This is a meeting where the teachers who teach subjects tested in NE are invited by the local education department official/education authority. The school ranks will be shown there. Thus, we will be so embarrassed if our school ranks the lowest. Then the education authority warns the low performing schools and suggests that they improve as hard as they possibly can. For us, it's like a 'teacher shaming' moment done in public.

Annually, teachers are invited by the district education department to check the result of NE. Each school should attend the meeting to see what number their school is ranked. After this school ratings disclosure, the teachers will be given a caution and advised to perform better and learn from the past mistakes. This kind of rankings display clearly causes teachers to feel ashamed since all the teachers there know who performed well and who did not, becoming a breeding ground for mental health problems, such as work pressure, burn-outs, stress, and anxiety.

\section{Teachers' Future Aspiration regarding English Examination for Their Students}

After decades of debate over the controversy of NE, the current ministry of education and culture Nadiem Makarim plans to discard NE from education

Journal on English as a Foreign Language, 10(2), 193-221

p-ISSN 2088-1657; e-ISSN 2502-6615 
assessment system in 2021 (The Jakarta Post, 2019). As confronted with this decision, the teachers demonstrated varying voices, with some desiring $\mathrm{NE}$ continuation while others going against it. Dalton and Florence argued that NE should be continued. Dalton said in a statement:

The NE outcome is the benchmark of our education quality. Complaints from local teachers and students, and schools can be used as an evaluation material. However, to measure student competence, NE is not final.

Additionally, Florence said:

NE is still reliable enough to measure school output. That's why it can still be used to identify school quality. Besides, NE being worth $40 \%$ for students' passing grade is still acceptably fair."

They hope that NE will still be always in place despite the rising controversies. NE will be used only for education quality mapping since students' abilities are demonstrated by the midterm and final assessment administered by schools. In addition, NE is likely to be a trigger for entities such as teachers, principals, students and parents to articulate their aspirations on education assessment. From there, the education authority will get input and advice for an education evaluation program. In contrast, Ava and Barbara are against NE continuation.

Ava said:

I agree if NE is abolished. NE does not reflect students' true abilities. And then there are other factors that also affect their achievements.

Additionally, Barbara said:

Why still use NE? I don't see the point in its implementation. Even though it [NE score] doesn't count as much now, it is somehow still used to apply for a school. Does it [NE score] cover all aspects? Does it represent students' overall skills? I don't think it actually does!

They believe that NE should be removed from the education system because it is not an authentic reflection of students' entire achievement, including attitude, skills, morals. These aspects can only be measured through daily observations, interactions and communications between teachers and students as mandated

Journal on English as a Foreign Language, 10(2), 193-221

p-ISSN 2088-1657; e-ISSN 2502-6615 
by K-13. Similarly, Elizabeth and Catalina were against the NE implementation. Elizabeth said:

I agree if $\mathrm{NE}$ is abolished. I am wondering why there is still a school exam when there is also NE. Isn't that redundant? And we are still being asked to collect scores that reflect school scores. We collect the accumulated scores from semester 1 to semester 5 . This should reflect the USBN test scores later.

Additionally, Catalina said:

It's good that the government will scrap NE from education system. To me, NE doesn't show the whole skills, only academic side. It's not a balanced education and seems very theoretical. To balance it out, the USBN was introduced and has been going along with NE. It's better to just implement USBN without NE because it's too much for us to deal with. Also, USBN is already reflective of students' abilities because the teachers do the assessment directly on a daily basis.

They think that there is redundancy when NE is administered along with the USBN, arguing that there should be only one test to represent students' achievement. Thus, teachers begin to doubt their own capability if their overall assessment score should be the parameter of USBN score. This proves worrisome to them as a score mismatch will raise a question, regardless of other factors affecting students' performance, such as anxiety, preparedness, and health issues. Catalina-a teacher from Calwell school-stated that matching the two scores shows distrust between the education authority and the school, making her feel as if the score issued by school were invalid and thus needed further verification. Elizabeth and Catalina suggested that NE be completely abolished, maintaining that it does more harm than good.

\section{DISCUSSION}

The goals of education in Indonesia is to improve students' potential so they become persons instilled with human values, such as being religious, morally adjusted, healthy, knowledgeable, competent, creative, independent, responsible and democratic (Law of the Republic of Indonesia Number 20 Year 2003 regarding National Education System, 2003). To achieve these, the government delegates the minister of national education and culture authorization to set the curriculum. Curriculum refers to plan and design for program and how the content in a program is transformed into a blueprint for

Journal on English as a Foreign Language, 10(2), 193-221

p-ISSN 2088-1657; e-ISSN 2502-6615 
teaching and learning which enables the wanted learning outcomes to be reached (Richards, 2013). Therefore, K-13 was developed, aiming to increase not only competency but also attitude, skills and knowledge of students. It is expected that K-13 would create intelligent young generation comprehensively with emotional, spiritual, and social intelligence. Conflicting with these missions, NE has otherwise significantly negatively affected teachers, diverting them from instilling the mandatory values to students. As a result, there are some possible drawbacks of NE in relation to ELT and teachers' professional practices. Alhadza and Zulkifli (2017) found that NE makes teachers narrow down the teaching materials so that they will cater for the needs of NE question items, focusing on repetitive teaching approach that leaves the students at risk of losing their chance to master English. Nuriana (2019) revealed that teachers have difficulty assessing students' attitude in the learning process as mandated by $\mathrm{K}-13$ due to time restriction for a big number of students. This finding is different from the current one in terms of the cause of teaching paradigm shift. The current study found that teachers focused heavily on teaching knowledge because NE is knowledge-oriented, which is in contrast with K-13 goals.

The current study reveals that English teachers tend to teach knowledge and ignore the aspects of attitude and skills because they must pursue the target, which is teaching what is tested in NE. This makes them teach Reading most frequently while the other skills are neglected, hoping great success to come. The Reading is often in the form of reading passage with multiple-choice questions. This kind of question may not engage students' high order thinking but involves only low order thinking. It evidently contradicts the goal of K-13, which is to shape students to be the future critical thinkers. Mustajib (2017) found that NE has caused attitude and skills to be eliminated from the education experience because of the narrowed curriculum. However, she did not touch upon the issue on the critical thinking elimination. K-13 has reduced the time allocated to ELT, which makes students have less chance to practice English communication, causing teachers to struggle to allocate time for Listening, Speaking, Reading, and Writing (Putra, 2012). This Reading domination clearly shows that students lack the opportunity to explore their holistic English skills despite teachers' intention to satisfy their needs.

Furthermore, the reading materials are usually aligned with the model of questions tested in NE. Since NE mainly tests students' mastery in interpersonal communication skill, it makes teachers focus their teaching on it. It is evident that some teachers assume teaching transactional communication skill as useless because it is never tested. Due to this heavily skewed purpose of

Journal on English as a Foreign Language, 10(2), 193-221

p-ISSN 2088-1657; e-ISSN 2502-6615 
teaching, the more important skills, such as speaking, is significantly taken for granted. Indrawati (2018) found that NE has caused teachers to teach through constant drills, neglecting the other materials that are beyond the simulation tests of NE. This might be the reason why teachers are complacent in teaching through drills. The current study shows that students' English comprehension is clearly compromised as NE makes teachers teach to the test since they will be sternly warned if their students fail or score low. The whole lessons and teaching materials are catered for topics that are commonly tested, hindering teachers from giving students varying topics that will otherwise be useful for their English communication. The skills of listening, reading, writing, and speaking should be taught consecutively so that the flow of the language learning becomes effectively smooth. Due to the inclination to $\mathrm{NE}$, the frequency of teaching Speaking is much less than Reading.

It is worth noting that teaching speaking is also important since students need to have communicative skills. They can exchange ideas and feelings to their counterparts so that the conversation will keep going. Such a skill can only be acquired through a big amount of daily practice. In communicative language teaching, Richards (2006) maintains that there are activities that teachers would want their students to do in the classroom when they are studying, including interaction between the learner and users of the language, collaborative creation of meaning, creating meaningful and purposeful interaction through language, and paying attention to the language one hears and trying to incorporate new forms into one's developing communicative competence.

The current study shows that all these activities have disappeared from daily ELT classrooms because teachers tend to prepare their students for NE by giving them reading passage drills. It can be assumed that NE keeps teachers away from the concept of communicative language teaching. In a more in-depth view, Celce-Murcia (2007) argues that communicative competence objectives should be based on linguistics, cultural anthropology, sociolinguistics, and other relevant areas of the social sciences and humanities. Teaching materials must be learner-driven and allow for communication while learning tasks need to be interactive whenever possible. Nevertheless, the current study reveals that the schools generally do not confirm this theory because they must rush and encompass everything for NE, leaving students' communicative competence severely compromised. Teachers drill and employ monotonous teaching methods for the preparation of NE. This evidently disables them to vary their teaching strategies that are based on teaching theories and principles. Effendi and Suyudi (2017) found that teachers believed that they are confined in a

Journal on English as a Foreign Language, 10(2), 193-221

p-ISSN 2088-1657; e-ISSN 2502-6615 
comfort zone as they have to repeat the same materials every year, discouraging them to improve themselves.

Nahdia and Trisnati (2019) found that teachers view NE mostly in positive side, implying they are more motivated to teach students through various methods and media to prepare their students for NE. Similarly, imposing significant penalties to test performance triggers students to work harder and learn more (Braun et al., 2011). It is because students still want to use the score of NE for future school applications. A former minister of education and culture, Muhadjir Effendy, stated that the admission of new students in 2019 is done through 3 ways, including school zonation under the quota of $90 \%$, merit-based admission 5\%, and residence change 5\% (Republika, 2019). Recently, the merit-based admission has increased to at most $30 \%$ due to a strong parents' enthusiasm to send their children to the high performing schools (Makarim, 2019b). This motivates students to study hard for their dream school. Consequently, teachers are encouraged to make them successfully meet the schools' passing grade. NE also still affects the way teachers see the goal of ELT in the sense that a good score is paramount. The current study reveals that an increase of NE-induced students' motivation appears to be a bogus assumption. Teachers observed that students became more diligent to study for the best NE score. When crosschecked, it was found that the students did so due to the fear of failing to score high, showing that such motivation is not from their heart (self-directed) but from the threat of NE. This proves true that NE makes students hardworking and strongly motivated when already sitting in the final year, which is grade 9. This shady motivation will likely not last nor give them learning satisfaction since K-13 demands that everyone has to have the sense of life-long learning spirit.

NE makes the government prioritize teachers' professionalism development program. The government focuses on improving teachers who teach subjects that are tested in NE. This current study revealed that teachers are proud to be English teachers because English is tested in NE. They feel they have some kind of privilege since they are on the spotlight of education success indicator. They believe other teachers do not have such a special status as they do. Ashadi and Rice (2016) found that teachers who taught NE-tested subjects are believed to gain more access to professional education. It is not uncommon that an English teacher is mandated to teach students sitting in the final year. Those who do not teach in the final year may be hindered from attending trainings carried out by the government. The central and district education

Journal on English as a Foreign Language, 10(2), 193-221

p-ISSN 2088-1657; e-ISSN 2502-6615 
department have a bigger ambition to hold a workshop for teachers who are teaching in the final year.

Teachers have shown two opposing views on NE in terms of motivation to teach English. Some say they are motivated when given the challenges every year while others are stressed out due to overloaded teaching materials within a short span of time. The motivated teachers think that they can develop themselves through the hurdles, making them teach their students as hard as they can so that the students will be well equipped with necessary knowledge and skills. They will make more effort to join any teacher training so that they will be more skilled at varying teaching methods, envisaging that they will be able to keep their students engaged to class with successful material delivery. In contrast, the teachers who feel stressed out and pressured by NE say that they have more teaching materials than the time allocated, cramming them in the shortest time possible. This pressure is further intensified by the administrative reports-such as various lessons plans - that need to be reported at differently scheduled times. As a result, their mental health is strained as they are haunted by the target that determines students' future and their own reputation as an English teacher. In contrast, Hartaty (2017) found that teachers' perception towards the implementation of NE is positive. They think that NE supports them to be more engaging and effective in ELT classroom instructions.

Ideally, education policy is made and decided participatorily by involving teachers as the field agent. Not only are they the policy implementers, they are also significant participants of policy reform. Unfortunately, these teachers have limited access to education policy making. Spolsky (2004) states that language beliefs or ideology influences language policy and affects the status of a language being learned at school and how it is treated. In Indonesia, English is regarded as a foreign language and is only learned at school in short hours; causing students to have less chance to fully learn and practice English. This also causes teachers to teach students through a direct teaching method, eliminating their critical thinking skills stimulation.

Additionally, Deville and Chalhoub-Deville (2011) argued that the main goal of high-stakes testing is to satisfy the standards set by the education authority. It also alters the focus of education (Braun et al., 2010). Thus, if teachers keep implementing NE-driven teaching strategies, the essence of intact learning experiences will possibly be at stake. In line with it, the National Education Standards Agency/BSNP (BSNP, 2017) demonstrates that NE is still used to map the quality of educational programs and/or educational units. In

Journal on English as a Foreign Language, 10(2), 193-221

p-ISSN 2088-1657; e-ISSN 2502-6615 
contrast, some other teachers argued that NE is not a valid representation of a well-rounded education, knowing that NE does not cover all language elements. They feel that NE does not reflect students' skills and morals mandated by K-13 and otherwise simply measures students' knowledge. Schools in Indonesia most often teach materials that are tested in NE, preventing students from gaining a thorough education, disabling them to experience the spirit of learning, and negating character-building education (Mustajib, 2017).

NE will have been replaced with Minimum Competency Assessment (AKM) and Character Survey by 2021 (Makarim, 2019b). The current study shows that the majority of teachers welcome this education reform since it gives them freedom to ELT classrooms to assess students' ability. They envision using a teaching method that stimulates critical thinking develops social skills with strong characters, and aspires innovation. Their aspiration is in line with dialogic teaching, an instruction where teachers accommodate students to have a talk and discussion among themselves under teachers' supervision (Alexander, 2017). This gives students the sense of owning the learning as they have the chance to give self-feedback, reflecting on their success and failure. Such a well-rounded education may be attained through a valid and reliable assessment tool and the success of a learning program is commonly determined by the result of assessment (Fulcher, 2003). It is also revealed that teachers are in favor of a formative assessment where it takes place all through the school year, used to recognize the basic information on students' skills and achievements to create instructions. As the school year runs by, teachers' knowledge of their students' needs, wants, lacks, and achievements will gradually be updated (Afflerbach, 2008).

To summarize, formative assessment is better than high-stakes testing since the former assesses the whole process of learning while the latter only tests a narrow element of learning conducted within one sitting. Formative assessment should be seen as the main foundation of a successful, well-rounded education.

\section{CONCLUSION}

NE has narrowed down the curriculum in the sense that the questions for NE are uniformed and focused mainly on reading skills that are in multiplechoice questions, likely stimulating only Low Order Thinking Skill (LOTS) and contradicting K-13 goals. Such K-13 divergence originated from the limited time allocation for English subject, barring teachers from promoting students' skills

Journal on English as a Foreign Language, 10(2), 193-221

p-ISSN 2088-1657; e-ISSN 2502-6615 
and attitude but prioritizing only knowledge. Low scores lead to teachers being warned and advised that they must improve. The warning and advice are always given on the spot at a teacher meeting where the school NE-based ranks are displayed, resulting in teacher shaming, mental devastation and loss of selfconfidence in teaching. NE also creates jealousy and discrimination between teachers because the government focuses on improving teachers who teach subjects that are tested in NE. Teachers have gradually been interested to take part in education policy reform, particularly in the process of designing curriculum and assessment. They must get involved in these projects considering they are the direct objects, participants, and reformers of education policy. The abolishment of NE will give teachers freedom to teach what students need with a more personalized assessment framework and possibly eliminate discrimination against teachers. The researchers strongly believe that the transition from high-stakes testing system to a freer ELT instruction will bring success to students' English learning process, eventually generating a well-rounded education. Therefore, future researchers may direct their research to teachers' strategies in coping with assessment changes, adjusting from NE to the new assessment system which emphasizes competency assessment and a character survey. They are also encouraged to scrutinize how education authorities determine the basic framework for the new ELT assessment.

\section{AKCNOWLEDGEMENTS}

We wish to thank the teachers who were willing to be interviewed, the education authority of the District Education Department of Yogyakarta who was helpful and cooperative during the process of data collection, and Yogyakarta State University that was quick to get us the permit for data collection.

\section{REFERENCES}

Afflerbach, P. (2008). Meaningful assessment for struggling adolescent readers. In S. Lenski \& J. Lewis (Eds.). Reading success for struggling adolescent learners (pp. 249-264). New York: Guilford.

Alexander, R. J. (2010). Children, their world, their education: Final report and recommendations of the Cambridge primary review. New York: Routledge.

Alexander, R. J. (2017). Towards dialogic teaching: Rethinking classroom talk (5th ed.). York: Logos.

Alhadza, A., \& Zulkifli, M. (2017). National examination and the quality of education in Indonesia. Advances in Social Sciences Research Journal, 4(21), 12. https://doi.org/10.14738/assrj.421.3613

Journal on English as a Foreign Language, 10(2), 193-221

p-ISSN 2088-1657; e-ISSN 2502-6615 
Angrist, J., \& Lavy, V. (2009). The effects of high stakes high school achievement awards: Evidence from a randomized trial. American Economic Review, 99(4), 1384-1414. https://doi.org/10.1257/aer.99.4.1384

Antaranews. (2018, April 30). Pembocor soal UNBK SMP di Surabaya terungkap, begini modusnya [The leaker of the school-based test Junior High School in Surabaya was revealed, this is the mode]. Retrieved from https:/Wwww.antaranews.com/berita/706101/pembocor-soal-unbk-smpdi-surabaya-terungkap-begini-modusnya

Ashadi, A., \& Rice, S. (2016). High stakes testing and teacher access to professional opportunities: Lessons from Indonesia. Journal of Education Policy, 31(6), 727-741. https://doi.org/10.1080/02680939.2016.1193901

$\mathrm{Au}, \mathrm{W}$. (2009). Social studies, social justice: W(h)ither the social studies in highstakes testing?. Teaching Education Quarterly, 36(1), 43-58. Retrieved from https:/files.eric.ed.gov fulltext/EJ851027.pdf

$\mathrm{Au}, \mathrm{W}$. (2011). Teaching under the new Taylorism: High-stakes testing and the standardization of the 21st century curriculum. Journal of Curriculum Studies, 43(1), 25-45. https://doi.org/10.1080/00220272.2010.521261

Barksdale-Ladd, M. A., \& Thomas, K. F. (2000). What's at stake in high-stakes testing: Teachers and parents speak out. Journal of Teacher Education, 51(5), 384-397. https://doi.org/10.1177/0022487100051005006

BBC Indonesia. (2017, April 14). Kasus bunuh diri siswa terkait ujian: USBN diminta ditinjau ulang [Student suicides related to exams: School-based test is requested to be reviewed]. Retrieved from https://www.bbc.com/indonesia/indonesia-39589093

Berliner, D. (2011). Rational responses to high stakes testing: The case of curriculum narrowing and the harm that follows. Cambridge Journal of Education, 41(3), 287-302. https://doi.org/10.1080/0305764X.2011.607151

Bishop, J. H. (1997). The effect of national standards and curriculum-based exams on achievement. The American Economic Review, 87(2), 260-264. Retrieved from https://digitalcommons.ilr.cornell.edu/cgi /viewcontent.cgi?referer=https: / kwww.google.com/\&httpsredir=1\&article=1142\&context=cahrswp

Boyce, C., \& Neale, P. (2006). Conducting in-depth interviews: A guide for designing and conducting in-depth interviews for evaluation input. New York: Pathfinder International.

Braun, A., Maguire, M., \& Ball, S. J. (2010). Policy enactments in the UK secondary school: Examining policy, practice and school positioning. Journal of Education Policy, 25(4), 547-560. https://doi.org/10.1080/02680931003698544 
Braun, A., Yamamoto, K., \& Kirsch, I. (2011). An experimental study of the effects of monetary incentives on performance on the 12th-grade NAEP reading assessment. Teachers College Record, 113(11), 2309-2344. Retrieved from https://eric.ed.gov /?id=EJ951108

BSNP. (2017). Kebijakan UN diubah untuk kuatkan tujuan dan fungsi UN [The NE policy was changed to strengthen the goals and functions of the NE]. Retrieved from https:/bsnp-indonesia.org/wp-content/uploads/2018/03/BukuSaku-UN-6-Des-2017-Edit-21-Maret-2018.pdf

Celce-Murcia, M. (2007). Rethinking the role of communicative competence in language teaching. In E. A. Soler \& M. P. S. Jordà (Eds.), Intercultural Language Use and Language Learning (pp. 41-57). Springer Netherlands.

Cochran-Smith, M. (2006). Policy, practice, and politics in teacher education. Thousand Oaks, CA: Corwin Press.

Cochran-Smith, M. (2003). Learning and unlearning: The education of teacher educators. Teaching and Teacher Education, 19(1), 5-28. https://doi.org/10.1016/50742-051X(02)00091-4

Coniam, D., \& Falvey, P. (2018). High-stakes testing: The impact of the LPATE on English language teachers in Hong Kong. Singapore: Springer Nature.

Crawford, J., \& Impara, J.C. (2001). Critical issues, current trends, and possible futures in quantitative methods. In V. Richardson (Ed.), Handbook of research on teaching (pp. 133-173). Washngton, DC: American Educational Research Association.

Darling-Hammond, L. (2010). The flat world and education: How America's commitment to equity will determine our future. New York: Teachers' College Press.

Deville, C., \& Chalhoub-Deville, M. (2011). Accountability-assessment under no child left behind: Agenda, practice, and future. Language Testing, 28(3), 307-321. https://doi.org/10.1177/0265532211400876

Diamond, J. B. (2012). Practice: Partial recoupling and educational opportunity. Education and Urban Society, 44(2), 151-182. https://doi.org/10.1177/0013124511431569

Dutro, E., \& Selland, M. (2012). I like to read, but I know I'm not good at it: Children's perspectives on high-stakes testing in a high-poverty school. Curriculum Inquiry, 42(3), 340-367. https://doi.org/10.1111/.1467873X.2012.00597.x

Effendi, T., \& Suyudi, I. (2017). The impacts of English national examination in Indonesia. Advances in Social Science, Education and Humanities Research, 82, 236-239. Retrieved from https:/www.atlantispress.com/proceedings/conaplin-16/25874167

Journal on English as a Foreign Language, 10(2), 193-221

p-ISSN 2088-1657; e-ISSN 2502-6615 
Franzak, J. K. (2004). Constructing struggling readers: Policies and experiences of eighth-grade readers. In J. Worthy, B., Maloch, J., Hoffman, D., Schallert \& C. Fairbanks (Eds). 53rd Yearbook of The National Reading Conference. (pp. 189-205). Oak Creek, WI: National Reading Conference.

Fulcher, G. (2003). Testing second language speaking. London: Longman/Pearson Education.

Guthrie, J. T. (2002). Preparing students for high-stakes test taking in reading. In A.E. Farstup \& S.J. Samuels (Eds.). What research has to say about reading instruction (pp. 370-389). Newark, Delaware: International Reading Association.

Harris, P., Smith, B. M., \& Harris, J. (2011). The myths of standardized tests. Plymouth, UK: Rowman \& Littlefield.

Hartaty, W. (2017). The impacts of the 2015 national examination policy in Indonesia on English language teaching. International Seminar on English Language and Teaching, 5, 355-358. Retrieved from http://ejournal.unp.ac.id/index.php/selt/article/view /8027/6129

Indrawati, T. (2018). Washback of English national examination on the teaching learning process. Research on English Language Teaching in Indonesia, 6(3), 60-68. Retrieved from https://core.ac.uk/download/pdf/230779373.pdf

Jones, B. D., \& Hargrove,T. (2003). The unintended consequences of high-stakes testing. Lanham, MD: Rowman \& Littlefield.

Kempf, A. (2016). The pedagogy of standardized testing: The radical impacts of educational standardization in the US and Canada. New York: Palgrave Macmillan.

Kurniasari, N. (2016). Hubungan antara intensitas zikir dengan kecemasan menjelang Ujian Nasional pada siswa SMA di MAN 1 Yogyakarta [The relationship between the intensity of remembrance with anxiety before the National Examination on high school students in MAN 1 Yogyakarta] (Unpublished Thesis). UIN Sunan Kalijaga, Yogyakarta, Indonesia]. Retrieved from http://digilib.uin-suka.ac.id/23465/1 09710052_BAB-I_IV-atauV_DAFTAR-PUSTAKA.pdf

Lengkanawati, N.S. (2005). EFL teacher's competence in the context of English curriculum 2004: Implications for EFL teacher education. TEFLIN Journal, 16(1), 79-92. http://dx.doi.org/10.15639 Aeflinjournal.v16i1 /79-92

Lichtman, M. (2010). Qualitative research in education: A user's guide. Thousand Oaks: Sage.

Maisaroh, E. N., \& Falah, F. (2011). Religiusitas dan kecemasan menghadapi ujian nasional (UN) pada siswa Madrasah Aliyah [Religiosity and

Journal on English as a Foreign Language, 10(2), 193-221

p-ISSN 2088-1657; e-ISSN 2502-6615 
anxiety facing national exams on Madrasah Aliyah students]. Proyeksi, 6(2), 78-88. https://doi.org/10.30659/p.6.2.78-88

Makarim, N. (2019a). Nadiem: Sederhanakan aturan standar pendidikan [Nadiem: Simplify the rules of education standards]. BSNP. Retrieved from https://bsnp-indonesia.org/2019/12/nadiem-sederhanakan-aturanstandar-pendidikan/

Makarim, N. (2019b). PPDB 2020 tetap sistem zonasi, kuota jalur prestasi ditambah [New student recruitment 2020 remains using the zonation system, the achievement-based quota is added]. BSNP. Retrieved from https://www.kemdikbud.go.id/main/blog 2019/12/ppdb-2020-tetapsistem-zonasi-kuota-jalur-prestasi-ditambah

Merdeka. (2013, May 29). Gita Saraswati: Siswi berprestasi di Medan tak lulus UN [Gita Saraswati: A student who excelled in Medan did not pass the National Examination]. Retrieved from https:/wwww.merdeka.com/peristiwa/gitasaraswati-siswi-berprestasi-di-medan-tak-lulus-un.html

Merriam, S. (2009). Qualitative research: A Guide to Design and Implementation. San Francisco: CA: Jossey-Bass.

Miles, M. B., Huberman, A. M., \& Saldaña, J. (2014). Qualitative data analysis. A method sourcebook. Thousand Oaks: Sage.

Mohajan, H. K. (2018). Qualitative research methodology in social sciences and related subjects. Journal of Economic Development, Environment and People, 7(1), 23-48. https://doi.org/10.26458 jedep.v7i1.571

Mukminin, A., Haryanto, E., Makmur, Failasofah, Fajaryani, N., Thabran, Y., \& Hamzah, S. A. N. (2013). The achievement ideology and top-down national standardized exam policy in Indonesia: Voices from local English teachers. Turkish Online Journal of Qualitative Inquiry, 4(4) 19-38. https://doi.org/10.17569 tojqi.03900

Mustajib. (2017). The impact of national examination on students' motivation and teachers' professionalism at English class in Mataram municipality year 2016. The Indonesian Journal of Language and Language Teaching, 2, 1$13 . \quad$ Retrieved from http://jolt.unram.ac.id/index.php/jolt/article/view /20/18

Nahdia, K., \& Trisnati, N. (2019). Examining washback of national examination: EFL teachers and students' perceptions. UNNES International Conference on English Language Teaching, Literature, and Translation, 188, 273-277. https://doi.org/10.2991/eltlt-18.2019.54

Nichols, S. L., \& Berliner, D. C. (2007). Collateral damage: How high-stakes testing corrupts America's schools. Cambridge, MA: Harvard Education Press.

Journal on English as a Foreign Language, 10(2), 193-221

p-ISSN 2088-1657; e-ISSN 2502-6615 
Nuriana, D. (2019). Kendala guru dalam memberikan penilaian sikap siswa pada proses pembelajaran berdasarkan kurikulum 2013 [Teacher's constraints in providing an assessment of student attitudes in the learning process based on the 2013 curriculum]. Madrosatuna: Journal of Islamic Elementary School, 2(2), 51-62. https://doi.org/10.21070/madrosatuna.v2i2.1970

Peraturan Menteri Pendidikan dan Kebudayaan Republik Indonesia Nomor 5 Tahun 2015 [Ministry of Education and Culture Regulation of the Republic of Indonesia Number 5 year 2015]. Retrieved from https:/Auk.staff.ugm.ac.id/atur/bsnp/un/201 5/Permendikbud52015KriteriaKelulusanPesertaDidikUN.pdf

Putra, K.A. (2012). Mengurai benang kusut pembelajaran bahasa Inggris [Unravel the tangles of English learning]. Radar Lampung Newspaper, pp. 7.

Republika. (2019, January 16). Banyak berubahkah PPDB 2019? [Are there many changes in the New Student Recruitment 2019?] Retrieved from https://www.republika.co.id/berita/nasional/newsanalysis/19/01/16/plenbt440-banyak-berubahkah-ppdb-2019

Richards, J. C. (2006). Communicative language teaching today. New York: Cambridge University Press.

Richards, J. C. (2013). Curriculum approaches in language teaching: Forward, central, and backward design. RELC Journal, 44(1), 5-33. https://doi.org/10.1177/0033688212473293

Roderick, M., \& Engel, M. (2001). The grasshopper and the ant: Motivational responses of low-achieving students to high-stakes testing. Educational Evaluation and Policy Analysis, 23(3), 197-227. https://doi.org/10.3102/01623737023003197

Saldaña, J. (2011). Fundamentals of qualitative research. New York: Oxford University Press.

Saukah, A., \& Cahyono, A. E. (2015). National exam in Indonesia and its implications to the teaching and learning of English. Jurnal Penelitian dan Evaluasi Pendidikan, 19(2), 243-255. https://doi.org/10.21831/pep.v19i2.5583

Setiyadi, B. (2009). The challenges of the teaching of English in Indonesia. A paper presented at professorship inauguration. University of Bandar Lampung, Indonesia.

Spolsky, B. (2004). Language policy. Cambridge, UK: Cambridge University Press.

Spring, J. (2004). American education. New York, NY: McGraw-Hill.

Journal on English as a Foreign Language, 10(2), 193-221

p-ISSN 2088-1657; e-ISSN 2502-6615 
Stobart, G. (2008). Testing times: The uses and abuses of assessment. New York: Routledge.

Sundayana, W., Meekaeo, P., Purnawarman, P., \& Sukyadi, D. (2018). Washback of English national exams at ninth-grade level in Thailand and Indonesia. Indonesian Journal of Applied Linguistics, 8(1), 167-176. https://doi.org/10.17509/ijal.v8i1.11478

The Jakarta Post. (2019, December 12). Listen up, students: Nadiem wants to do away with national exam. Retrieved from https://www.thejakartapost.com /news/2019/12/12/isten-up-students-nadiem-wants-to-do-away-withnational-exam.html

Thomas, R.M. (2005). High-stakes testing: Coping with collateral damage. New Jersey, USA: Lawrence Erlbaum Associates.

Undang-Undang Republik Indonesia No. 20 Tahun 2003 Tentang Sistem Pendidikan Nasional [Republic of Indonesia's Constitution Number 20 Year 2003 about National Education System]. Retrieved from http://simkeu.kemdikbud.go.id//ndex.php/peraturan1/8-uu-undangundang /2-uu-no-20-tahun-2003-tentang-sistem-pendidikan-nasional

Wepner, S. B. (2006). Teaching gone amok: Leave no teacher candidate behind. Teacher Education Quarterly, 33(1), 135-149. Retrieved from https:/files.eric.ed.gov/fulltext/EJ795202.pdf

Yulia, Y. (2014). An evaluation of English language teaching programs in Indonesian Junior High Schools in Yogyakarta province (Unpublished Ph.D thesis). RMIT University, Melbourne, Australia. Retrieved from http://researchbank.rmit.edu.au/eserv/rmit:160956/Yulia.pdf

Zhang, Y., \& Wildemuth, B., M. (2009). Unstructured interviews. In B. M. Wildemuth (Ed.), Applications of social research methods to questions in information and library science (pp. 222-231). London: Libraries Unlimited.

\section{Authors' Brief CV}

Laser Romios is a postgraduate student of Yogyakarta State University, Indonesia. His research interests are education policy, Intercultural Communicative Language Teaching (ICLT) and translation \& interpreting. He has translated a Malay folklore book and academic \& non-academic documents. He has also been on interpreting assignments for formal and non-formal meetings.

Ashadi is a lecturer in the English Education Department, Yogyakarta State University, Indonesia. His research interests include teacher professional

Journal on English as a Foreign Language, 10(2), 193-221

p-ISSN 2088-1657; e-ISSN 2502-6615 
development, curriculum and instruction, Teaching English as a Foreign Language (TEFL), and equity in education. He has published several journal articles and is currently completing a textbook on English teaching.

Widyastuti Purbani is a lecturer in the English Literature Department, Yogyakarta State University. Her main interests include Children's Literature, Eco-criticism and Critical Literacy. She has published some articles and presented papers in some conferences. 